\title{
KUAT TEKAN BETON MUTU TINGGI MENGGUNAKAN KOMPARASI AGREGAT GAMALAMA, AGREGAT MERAPI DAN AGREGAT KALI PROGO
}

\author{
Hakas Prayuda ${ }^{1}$, As'at Pujianto ${ }^{2}$ \\ ${ }^{1}$ Jurusan Teknik Sipil, Fakultas Teknik, Universitas Muhammadiyah Yogyakarta. Jalan Lingkar Selatan, \\ Tamantirto, Kasihan, Bantul, Daerah Istimewa Yogyakarta, 55183 \\ hakasprayuda@umy.ac.id \\ ${ }^{2} J u r u s a n$ Teknik Sipil, Fakultas Teknik, Universitas Muhammadiyah Yogyakarta. Jalan Lingkar Selatan, \\ Tamantirto, Kasihan, Bantul, Daerah Istimewa Yogyakarta, 55183 \\ pujiantoasat@umy.ac.id
}

\begin{abstract}
ABSTRAK
Penelitian ini membahas perbandingan hasil kuat tekan beton dengan menggunakan variasi jenis asal agregat halus dan kasar dari tiga lokasi yang berbeda. Agregat halus dan kasar diambil dari Gunung Gamalama, Provinsi Maluku Utara, Agregat dari Gunung Merapi Kabupaten Sleman dan Agregat dari Kali Progo, Kabupaten Kulon Progo. Tujuan dari penelitian ini untuk mengetahui penggunaan jenis agregat dari ketiga lokasi tersebut dalam aplikasi penggunaan beton mutu tinggi. Agregat terlebih dahulu dilakukan pemeriksaan sifat fisik dan mekanis yang dibutuhkan. Beton yang digunakan dalam penelitian ini berbentuk silinder berukuran diameter $15 \mathrm{~cm}$ dengan tinggi $30 \mathrm{~cm}$ sebanyak 27 benda uji. Pada saat beton masih segar, dilakukan pengujian slump untuk mengetahui nilai workability nya yang kemudian dilakukan pengujian kuat tekan beton pada umur 7,14 dan 28 hari. Dari hasil pengujian ini, seluruh beton dari ketiga daerah ini dapat digunakan untuk beton mutu tinggi diatas $50 \mathrm{MPa}$ dengan agregat asal kali progo merupakan agregat yang menghasilkan kuat tekan beton paling tinggi.
\end{abstract}

Kata kunci: Beton Mutu Tinggi, Gamalama, Merapi, Kali Progo, Kuat Tekan

\begin{abstract}
This study discusses the comparison of the compressive strength of concrete using various types of fine and coarse aggregate origin from three different locations. Fine and coarse aggregates are taken from Mount Gamalama, North Maluku Province, Aggregates from Mount Merapi, Sleman Regency and Aggregates from Progo River, Kulon Progo Regency. The purpose of this study was to determine the use of aggregate types from these three locations in applications in high strength concrete. Aggregates are first tested for the physical and mechanical properties needed. The sample used in this study is cylindrical in size with a diameter of $15 \mathrm{~cm}$ with a height of $30 \mathrm{~cm}$ as many as 27 test objects. When the concrete is still fresh, a slump test is used to determine the workability value which is then tested for concrete compressive strength at the age of 7.14 and 28 days. From the results of this test, all concrete from these three locations can be used for high strength concrete above $50 \mathrm{MPa}$ with aggregate from Progo River producing the highest concrete compressive strength.
\end{abstract}

Keywords: High Strength Concrete, Gamalama, Merapi, Progo River, Compressive Strength

\section{PENDAHULUAN}

Beton mutu tinggi merupakan beton dengan perlakuan khusus yang tidak dapat selalu dicapai hanya dengan penggunaan material konvensional (Ervianto dkk, 2016). Beton mutu tinggi digunakan untuk bahan bangunan struktur seperti struktur bangunan gedung bertingkat tinggi, struktur jembatan atau bangunan yang memerlukan beton dengan kuat tekan lebih dari $40 \mathrm{MPa}$ (Luga dan Atis, 2016). beton pada umumnya terdisi dari beberapa material bahan penyusun yaitu air, semen, agregat halus dan agregat kasar dengan suatu takaran tertentu.

Perencanaan suatu beton dituntut adanya hasil perencanaan yang menghasilkan beton dengan kuat tekan yang sesuai dengan yang dinginkan. Material alam untuk membuat suatu beton mampu didapatkan dari pegunungan, sungai dan pantai. Pada penelitian ini bertujuan untuk membandingkan kuat tekan beton dengan variasi asal agregat serta membandingkan sifat dari masing-masing agregat. Karakteristik dari agregat sangat mempengaruhi kuat tekan beton yang dihasilkan sebab agregat merupaka lebih dari $50 \%$ bahan pengisi dalam pembuatan beton.

Beberapa penelitian mengenai pemanfaatan agregat dari kali progo pernah dilakukan oleh Ervianto dkk., (2016), dari hasil pemeriksaan diperoleh bahwa agregat halus termasuk dalam daerah 2 serta kadar lumpur 
4,53\% sedangkan agregat halus memperoleh nilai keausan $21,36 \%$. Hal serupa juga pernah dilakukan oleh (Pratiwi dkk, 2016) dan (Ikhsan dkk, 2017).

Pada penelitian ini dilakukan pengujian sifat agregat dari masing-masing daerah. Pengujian agregat halus yang dilakukan adalah pengujian gradasi butiran, modulus halus butir, berat jenis, kadar air, nilai penyerapan, berat satuan hingga ke kadar lumpur. Sedangkan agregat kasar pada penelitian ini dilakukan pengujian nilai keausan, kadar air, berat jenis, berat satuan, kadar lumpur dan nilai penyerapan. Beton di buat sebanyak 27 benda uji dengan ukuran diameter $15 \mathrm{~cm}$ dan tinggi $30 \mathrm{~cm}$ yang diuji kuat tekan pada umur 7, 14 dan 28 hari.

\section{SIFAT FISIK AGREGAT}

Agregat adalah butiran mineral alami yang berfungsi sebagai bahan pengisi dalam campuran mortal atau beton. Agregat ini kira-kira menempati sebanyak $70 \%$ volume mortal atau beton. Walaupun namanya hanya sebagai bahan pengisi, akan tetapi agregat sangat berpengaruh terhadap sifat-sifat mortar/betonnya, sehingga pemilihan agregat merupakan suatu bagian penting dalam pembuatan mortar/beton, (Tjokrodimuljo, 2007). Agregat halus adalah agregat dengan besar butir maksimum 4,75 mm. Agregat halus juga disebut dengan pasir. Adapun syaratsyarat halus yang baik digunakan untuk bahan campuran beton normal menurut (Mulyono, 2005) antara lain:

a. Modulus halus butir 1.5 sampai 3.8.

b. Kadar lumpur atau bagian yang lebih kecil dari 70 mikron $(0,074 \mathrm{~mm})$ maksimal 5\%.

c. Kadar zat organik yang terkandung yang ditentukan dengan mencampur agregat halus dengan larutan natrium sulfat $\left(\mathrm{NaSO}_{4}\right) 3 \%$, jika dibandingkan dengan warna standar / pembanding tidak lebih tua dari pada warna standar.

d. Kekerasan butiran jika dibandingkan dengan kekerasan butir pasir pembanding yang berasal dari pasir kwarsa bangka memberikan angka tidak lebih dari 2.20.

e. Kekekalan (jika diuji dengan natrium sulfat bagian yang hancur maksimum 10\%, dan jika di pakai magnesium sulfat bagian yang hancur maksimum 15\%).

Agregat kasar adalah agregat dengan besar butir lebih dari 4,75 mm. Agregat kasar juga disebut kerikil, batu pecah, ataupun split. Adapun karakteristik agregat kasar yang perlu diperhatikan diantaranya:

a. Gradasi Agregat Kasar adalah distribusi dari ukuran agregat atau proporsi dari macam-macam ukuran butir agregat berdasarkan analisa saringan.

b. Modulus Halus Butir (HMB), spesifikasi modulus halus butiran agregat kasar, yaitu 5,5\%-8,5\%.

c. Absorpsi dan Berat Jenis (Spesific Gravity), spesifikasi agregat untuk beton normal adalah berat jenis agregat kasar yaitu $1,60-3,20 \mathrm{~kg} /$ liter.

d. Berat volume agregat kasar, spesifikasi berat volume agregat kasar, yaitu 1,6-1,9 kg/liter.

e. Kadar Air Agregat Kasar, spesifikasi kadar air agregat kasar, yaitu 0,5\%-2,0\%.

f. Persentase Keausan, spesifikasi keausan agregat beton, yaitu 15\%-50\%.

Agregat kasar pada umumnya berbutir lebih besar dari 4,80 mm, contoh agregat kasar seperti, kerikil, kericak, batu pecah, atau split. Kerikil sebagai hasil desintregasi alami dari batuan atau berupa batu pecah yang diperoleh dari indrustri pemecahan batu dan mempunyai ukuran butir antara $5 \mathrm{~mm}$ sampai $40 \mathrm{~mm}$. Menurut BSN (2002), bahwa agregat kasar (kerikil/batu pecah) yang akan dipakai untuk membuat campuran beton harus memenuhi persyaratan-persyaratan sebagai berikut ini :

a. Kerikil atau batu pecah harus terdiri dari butir-butir yang keras dan tidak berpori serta mempunyai sifat kekal (tidak pecah atau hancur oleh pengaruh cuaca seperti terik matahari atau hujan). Agregat yang mengandung butir-butir pipih hanya dapat dipakai apabila jumlah butir-butir pipih tersebut tidak melebihi $20 \%$ dari berat agregat seluruhnya.

b. Agregat kasar tidak boleh mengandung bahan yang reaktif terhadap alkali jika agregat kasar digunakan untuk membuat beton yang akan mengalami basah dan lembab terus menerus atau yang akan berhubungan dengan tanah basah. Agregat yang reaktif terhadap alkali boleh untuk membuat beton dengan semen yang kadar alkalinya dihitung setara Natrium Oksida tidak lebih dari 0,6 \%, atau dengan menambahkan bahan yang dapat mencegah 12 terjadinya pemuaian yang dapat membahayakan oleh karena reaksi alkali agregat tersebut.

c. Agregat kasar tidak boleh mengandung bahan-bahan yang dapat merusak beton seperti bahan-bahan yang reaktif sekali dan harus dibuktikan dengan percobaan warna dengan laruta $\mathrm{NaOH}$.

d. Agregat kasar tidak boleh mengandung lumpur lebih dari 1\% (terhadap berat kering) dan apabila mengandung lebih dari $1 \%$, agregat kasar tersebut harus dicuci.

e. Ukuran butir agregat kasar maksimum tidak boleh lebih daripada 1/5 jarak terkecil antarabidang-bidang samping cetakan, 1/3 dari tebal pelat beton, 3/4 dari jarak bersih antar tulangan atau berkas tulangan. 
Pada pengujian ini dilakukan pemeriksaan sifat agregat yang bertujuan mengetahui sifat atau karakteristik agregat yang diperoleh. Pengujian yang dilakukan adalah sebagai berikut.

\section{Analisis Gradasi Butiran}

Gradasi agregat adalah distribusi ukuran butir dari suatu agregat. Bila butir-butir agregat mempunyai ukuran butir yang sama (seragam) maka volume porinya besar dan kemampatannya rendah. Sebaliknya, apabila ukuran butirnya bervariasi maka volume porinya rendah dan kemampatannya tinggi. Sehingga, hal tersebut perlu diadakan pemeriksaan gradasi agregat dalam pembuatan beton. Pasir dikelompokkan berdasarkan gradasi kekasaran butirannya menjadi beberapa daerah seperti Tabel 1.

Tabel 1 Gradasi kekasaran pasir (Mulyono, 2005)

\begin{tabular}{ccccc}
\hline $\begin{array}{c}\text { Lubang } \\
(\mathrm{mm})\end{array}$ & Daerah 1 & Daerah 2 & Daerah 3 & Daerah 4 \\
\hline 10 & 100 & 100 & 100 & 100 \\
4,8 & $90-100$ & $90-100$ & $90-100$ & $95-100$ \\
2,4 & $60-95$ & $75-100$ & $85-100$ & $95-100$ \\
1,2 & $30-70$ & $55-90$ & $75-100$ & $90-100$ \\
0,6 & $15-34$ & $35-59$ & $70-79$ & $80-100$ \\
0,3 & $5-20$ & $8-30$ & $12-40$ & $15-50$ \\
0,15 & $0-10$ & $0-10$ & $0-10$ & $0-15$ \\
\hline
\end{tabular}

Modulus halus butir adalah suatu indeks yang dipakai untuk menjadi ukuran kehalusan atau kekasaran butirbutir agregat. Semakin besar nilai modulus halus menunjukkan bahwa makin besar butir-butir agregatnya. Pada umumnya pasir mempunyai modulus halus butir antara 1,5 sampai 3,8, adapun modus halus butir krikil biasanya diantara 5 dan 8 . Secara matematis nilai modulus halus butir dan modulus butir campuran dapat dinyatakan sebagai berikut.

$$
\begin{aligned}
& M H B=\frac{\Sigma \% \text { berat tertahan kumulatif }}{\Sigma \% \text { berat tertahan }} . \\
& W=\frac{K-C}{C-P} \times 100 \% \ldots \ldots \ldots \ldots \ldots \ldots \ldots \ldots \ldots \ldots
\end{aligned}
$$

dengan:

MHB $=$ modulus halus butir

$\mathrm{W}=$ persentase berat agregat halus terhadap berat agregat kasar

$\mathrm{K}=$ modulus halus butir agregat kasar

$\mathrm{P}=$ modulus halus butir agregat halus

$\mathrm{C}=$ modulus halus butir agregat campuran

\section{Berat Jenis dan Penyerapan Air}

Berat jenis adalah perbandingan berat tersebut terhadap volume benda itu sendiri. Sedangkan penyerapan berarti tingkat atau kemampuan untuk menyerap air. Nilai yang disarankan untuk berat jenis lebih dari 2,50 dan penyerapan kurang dari 3\%. Berat jenis agregat dikelompokkan berdasarkan klasifikasi seperti Tabel 2 berikut.

Tabel 2 Klasifikasi berat jenis agregat (Tjokrodimuljo, 2007)

\begin{tabular}{cc}
\hline Agregat Halus (Pasir) & Agregat kasar (Kerikil) \\
\hline Ringan $(<2,0)$ & Ringan $(<2,0)$ \\
Normal $(2,5-2,7)$ & Normal $(2,5-2,7)$ \\
Berat $(>2,8)$ & Berat $(>2,8)$ \\
\hline
\end{tabular}

Secara matematis nilai berat jenis dapat dinyatakan dalam persamaan berikut ini.

$$
B j=\frac{w_{b}}{w_{a}}
$$

dengan:

$\mathrm{B}_{\mathrm{j}}=$ berat jenis,

$\mathrm{W}_{\mathrm{a}}=$ berat air dengan volume air sama dengan volume butir agregat (gram),

$\mathrm{W}_{\mathrm{b}}=$ berat butir agregat (gram).

\section{Pengujian Kadar Air}

Kadar air agregat adalah perbandingan antara berat air yang tergantung dalam agregat dengan agregat dalam keadaan kering. Jumlah air yang terkandung di dalam agregat perlu diketahui, karena akan mempengaruhi 
jumlah air yang diperlukan didalam campuran beton. Agregat yang banyak mengandung air, akan membuat FAS yang ada didalam campuran beton semakin banyak. Kadar air dapat dihitung dengan persamaan berikut.

$$
K A=\frac{w_{1}-w_{2}}{w_{2}}
$$

dengan:

$\mathrm{KA}=$ kadar air $(\%)$,

$\mathrm{W}_{1}=$ berat basah $($ gram $)$,

$\mathrm{W}_{2}=$ berat kering oven (gram).

\section{Pengujian Berat Satuan}

Berat satuan agregat adalah rasio antara berat agregat dan isi/volume. Berat isi agregat diperlukan dalam perhitungan bahan campuran beton. Perhitungan berat satuan dapat dihitung dengan persamaan berikut.

$$
B_{\text {sat }}=\frac{w_{b}}{V_{t}}
$$

dengan:

$B_{\text {sat }}=$ berat satuan $\left(\mathrm{kg} / \mathrm{cm}^{3}\right)$,

$\mathrm{W}_{\mathrm{b}}=$ berat butir-butir agregat dalam bejana $(\mathrm{kg})$,

$\mathrm{V}_{\mathrm{t}}=\mathrm{V}_{\mathrm{b}}+\mathrm{V}_{\mathrm{p}}$

$\mathrm{V}_{\mathrm{t}}=$ volume total bejana $\left(\mathrm{m}^{3}\right)$,

$\mathrm{V}_{\mathrm{b}}=$ volume butiran agregat dalam bejana $\left(\mathrm{m}^{3}\right)$,

$\mathrm{V}_{\mathrm{p}}=$ Volume pori terbuka antar butir-butir agregat dalam bejana.

\section{Pemeriksaan Kadar Lumpur}

Lumpur adalah gumpalan atau lapisan yang menutupi permukaan agregat dan lolos ayakan No.200. Kandungan lumpur pada permukaan butrian agregat akan mempengaruhi kekuatan ikatan antara pasta semen dan agregat sehingga mengurangi kekuatan dan ketahanan beton. Klasifikasi kadar lumpur agregat halus dan kasar dapat dilihat pada Tabel 3.

Tabel 3 Klasifikasi kadar lumpur pada agregat (BSN, 1989)

\begin{tabular}{cc}
\hline Agregat Halus (Pasir) & Agregat kasar (Kerikil) \\
\hline Bersih $(0 \%-3 \%)$ & Bersih $(<1 \%)$ \\
Sedang $(3 \%-5 \%)$ & \\
Kotor $(5 \%-7 \%)$ & \\
\hline
\end{tabular}

\section{Pengujian Keausan}

Pemeriksaan keausan agregat adalah untuk mengetahui angka keausan suatu agregat, yang dinyatakan dengan perbandingan antara berat bahan yang aus lolos saringan No. 12 terhadap berat mula-mula dalam persen (\%) dan juga sebagai acuan untuk menentukan ketahan agregat kasar terhadap keausan dengan menggunakan mesin abrasi Los Angeles. Persyaratan untuk kekuatan agregat normal dapat dilihat pada Tabel 4 sebagai berikut.

Tabel 4 Persyaratan kekuatan agregat kasar untuk beton normal (Tjokrodimuljo, 2007)

\begin{tabular}{cccc}
\hline $\begin{array}{c}\text { Kelas dan Mutu } \\
\text { Beton }\end{array}$ & $\begin{array}{c}\text { Bejana Rudeloff maksimum bagian yang } \\
\text { hancur, menembus ayakan 2mm (\%) } \\
\text { Ukuran butir 19-30 } \\
(\mathrm{mm})\end{array}$ & $\begin{array}{c}\text { Ukuran butir } 9,5-19 \\
(\mathrm{~mm})\end{array}$ & $\begin{array}{c}\text { Mesin Los Angeles } \\
\text { maksimum bagian yang } \\
\text { hancur, menembus } \\
\text { ayakan 1,7 mm (\%) }\end{array}$ \\
\hline $\begin{array}{c}\text { Kelas I mutu B0 dan } \\
\text { B1 }\end{array}$ & 30 & 32 & 50 \\
$\begin{array}{c}\text { Kelas II mutu K-125 } \\
(\mathrm{fc}=10 \mathrm{MPa}) \text { sampai } \\
(\mathrm{fc}=20 \mathrm{MPa})\end{array}$ & 22 & 24 & 40 \\
$\begin{array}{c}\text { Kelas III mutu di atas } \\
\text { K-225 (fc'=20 MPa) }\end{array}$ & 14 & 16 & 27 \\
\hline
\end{tabular}

\section{KUAT TEKAN BETON}

Menurut BSN (2002) beton adalah campuran antara semen portland atau semen hidraulik yang lain, agregat halus, agregat kasar dan air, dengan atau tanpa bahan tambahan membentuk masa padat, sedangkan yang di 
maksud beton normal adalah beton yang mempunyi berat isi (2200-2500) $\mathrm{kg} / \mathrm{m}^{3}$. Terdapat juga agregat halus (pasir) alam sebagai hasil disintegrasi secara 'alami' dari batuan atau pasir yang dihasilkan oleh industri pemecah batu dan mempunyai ukuran butir terbesar 5,0 mm, sedangkan agregat kasar (kerikil) sebagai hasil disintegrasi dari batuan atau berupa batu pecah yang diperoleh dari industri pemecah batu dan mempunyai ukuran butir antara $5 \mathrm{~mm}$ sampai $40 \mathrm{~mm}$.

Menurut Tjokrodimuljo (2007) beton dapat mempunyai kuat tekan yang sangat tinggi, tetapi kuat tariknya sangat rendah. Kondisi yang demikian, yaitu rendahnya kuat tarik, pada elemen struktur yang betonnya mengalami tagangan tarik diperkuat dengan batang baja tulangan sehingga terbentuk suatu struktur komposit, dan kemudian dikenal dengan sebutan beton bertulang. Khusus beton saja yang tidak bertulang disebut beton tampa tulang (plain concrete). Untuk struktur tertentu yang tidak menginginkan retak tarik pada beton misalnya, dilakukan manipulasi (strategis) dengan memberikan tegangan tekan awal sebelum struktur dibebani, yaitu pada struktur beton prategang (prestressed concrete).

Kuat tekan beton merupakan parameter utama yang harus diketahui dan dapat memberikan gambaran tentang hampir semua sifat-sifat mekanisnya yang lain dari beton. Walaupun dalam beton terdapat tegangan tarik yang kecil, diasumsikan bahwa semua tegangan tekan didukung oleh beton tersebut. Beton dengan kinerja baik dapat dilihat dari kuat tekan yang dihasilkan. Semakin tinggi kuat tekan yang dihasilkan, maka beton tersebut memiliki mutu beton yang baik. Faktor yang mempengaruhi kekuatan beton adalah proporsi campuran, pengadukan pada saat pembuatan, pembuatan, pemadatan dan perawatan beton itu sendiri. Kuat tekan silinder beton dapat dihitung dengan Persamaan 6 .

$$
\mathrm{Fc}=\frac{P}{A}
$$

dengan:

$\mathrm{fc}^{\prime}=$ kuat tekan silinder beton $(\mathrm{MPa})$,

$\mathrm{P}=$ Beban tekan maksimum $(\mathrm{N})$,

$\mathrm{A}=$ luas bidang tekan $\left(\mathrm{mm}^{2}\right)$.

Kekuatan tekan adalah kemampuan beton untuk menerima gaya tekan persatuan luas. Kuat tekan beton mengidentifikasikan mutu dari sebuah struktur. Semakin tinggi kekuatan struktur dikehendaki, semakin tinggi pula mutu beton yang dihasilkan (Mulyono, 2005). Nilai kuat tekan beton didapat dari pengujian standar dengan benda uji yang digunakan berbentuk silinder. Dimensi benda uji standar adalah tinggi $300 \mathrm{~mm}$ dan diameter 150 $\mathrm{mm}$. Tata cara pengujian yang umumnya dipakai adalah standar ASTM C39-86. Kuat tekan masing-masing benda uji ditentukan oleh tegangan tekan tertinggi (fc') yang dicapai benda uji umur 28 hari akibat beban tekan selama percobaan.

Kekuatan karakteristik, kekuatan tekan, tegangan dan regangan, susut dan rangkak, reaksi terhadap temperatur, keawetan dan kekedapan terhadap air. Dari semua sifat tersebut yang terpenting adalah kekuatan tekan beton karena merupakan gambaran dari mutu beton yang ada kaitannya dengan struktur beton, adapun hal-hal yang mempengaruhi kuat tekan beton, sebagai berikut :

a. Pengaruh cuaca berupa pengembangan dan penyusutan yang diakibatkan oleh pergantian panas dan dingin.

b. Daya perusak kimiawi, seperti air laut (garam), asam sulfat, alkali, limbah, dan lain-lain.

c. Daya tahan terhadap aus (abrasi) yang disebabkan oleh gesekan orang berjalan kaki, lalu lintas, gerakan ombak, dan lain-lain.

\section{METODOLOGI PENELITIAN}

\section{Bahan Penelitian}

Lokasi penelitian ini dilakukan di Laboratorium Mekanika Bahan Universitas Muhammadiyah Yogyakarta. Bahan-bahan pembuatan beton yang digunakan pada penelitian ini adalah:

a. Agregat kasar (split) berupa batu pecah yang berasal dari letusan Gunung Gamalama, Kota Ternate dan letusan Gunung Merapi dan Kali Progo.

b. Agregat halus yang dipakai berasal dari letusan Gunung Gamalama, Kota Ternate dan letusan Gunung Merapi dan Kali Progo.

c. Air diambil dari Laboratorium Teknologi Bahan Konstruksi, Jurusan Teknik Sipil, Fakultas Teknik, Universitas Muhammadiyah Yogyakarta

d. Semen yang digunakan adalah semen Holcim.

e. Bahan tambah yang digunakan dalam penelitian ini adalah Superplasticizer (Sikament-NN) untuk kuat tekan awal tinggi, yang diproduksi dari PT. Sika Nusantara Pratama. Digunakan sebanyak 1\% dari berat semen. 


\section{Materi Penelitian}

Pelaksanaan penelitian ini dimulai dari persiapan bahan dan alat, pemeriksaan bahan susun, pembuatan rancang campur beton (mix design) dengan memakai hitungan sesuai standar SK SNI-03-2847 2002, perawatan benda uji (curing) hingga pengujian kuat tekan beton. Pengujian kuat tekan Beton dilakukan dengan mesin uji tekan merk Hung Ta $150 \mathrm{MPa}$, yang secara langsung dapat memberikan nilai kuat tekan benda uji, dengan beban yang dapat dibaca pada skala pembebanan. Pengujian dilakukan di Laboratorium Teknologi Bahan Konstruksi Universitas Muhammadiyah Yogyakarta. Beban maksimum yang dapat diterima oleh benda uji dapat diketahui pada saat angka penunjuk tekanan mencapai nilai tertinggi yang diikuti hancur atau retaknya Beton setelah menerima beban maksimum. Analisis dan hasil data dapat dilakukan setelah data itu diolah.

\section{Mix Design}

Dalam perancangan campur bahan-bahan penyusun beton (mix design) ini berdasarkan SK SNI 03-2834-2002 (Tjokrodimujo, 2007). Perancangan campuran beton ini bertujuan untuk mengetahui komposisi atau proporsi bahan-bahan untuk penyusun beton tersebut. Hal ini dilakukan agar dapat memenuhi syarat teknis secara ekonomis dan bisa sesuai dengan hasil yang kita inginkan. Data hasil perancangan campuran beton dapat dilihat pada Tabel 5 .

Tabel 5 Komposisi Material Penyusun dalam $1 \mathrm{~m}^{3}$ beton

\begin{tabular}{lcc}
\hline & Bahan & Kebutuhan $(\mathrm{Kg})$ \\
\hline Air & 175.10 \\
Semen & 465.91 \\
Agregat Halus & 533.73 \\
Agregat Kasar & 1245.37 \\
Superplastisizer & 4.65 \\
Berat Rencana & 2424.77 \\
\hline
\end{tabular}

Pada penelitian ini menggunakan kuat tekan rencana sebesar $50 \mathrm{MPa}$ dengan menggunakan superplastisizer sebesar 1\% terhadap berat semen. Berdasarkan Tabel 5 diperoleh jumlah air sebesar $175.101 / \mathrm{m}^{3}$ hal tersebut diperoleh setelah dilakukan pengurangan air sebesar 15\% dari kebutuhan air awal, hal ini dikarenakan bahwa penggunaan superplastisizer dapat mengurangi jumlah air hingga 30\%. Jumlah semen yang digunakan sebesar $465.91 \mathrm{~kg}$, agregat halus sebesar $533.73 \mathrm{~kg}$, agregat kasar sebesar $1245.37 \mathrm{~kg}$ sedangkan bahan tambah superplastisizer sebesar $4.65 \mathrm{~kg}$. Berat rencana yang dihasil kan dalam penelitian ini sebesar $2424.77 \mathrm{~kg}$ sedangkan faktor air semen yang diperoleh sebesar 0.375. Pada Gambar 1 terlihat jelas prosentase bahan penyusun beton dalam $1 \mathrm{~m}^{3}$, semen hanya sekitar $19 \%$ dari total kebutuhan material sedangkan air hanya $7 \%$ dari total persentase bahan penyusun. Sedangkan agregat terdiri dari $74 \%$ bahan penyusun beton dimana agregat kasar sebesar 52\% dan agregat halus sebesar 22\%. Superplastisez merupakan komponen terkecil dalam bahan penyusun beton, persentasenya hanya sebesar $0.19 \%$ dari total keseluruhan bahan penyusun beton.

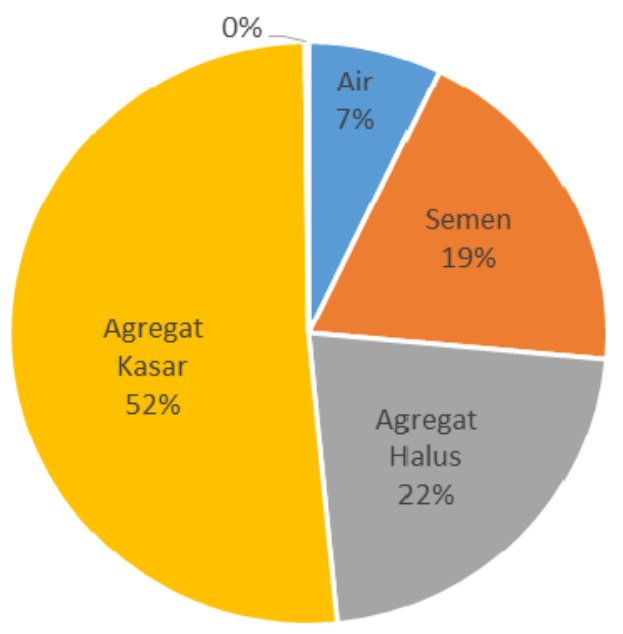

Gambar 1 Prosentase Material Penyusun dalam $1 \mathrm{~m}^{3}$ beton 


\section{HASIL DAN PEMBAHASAN}

\section{Pemeriksaan Sifat Agregat Halus dan Kasar}

Pemeriksaan sifat dari agregat halus dilakukan untuk mengetahui apakah seluruh agregat yang digunakan memenuhi persyaratan atau tidak. Pengujian agregat halus yang dilakukan meliputi pemeriksaan kadar air, berat jenis, kadar lumpur, gradasi butiran, penyerapan hingga berat satuan. Adapaun hasil pemeriksaan dapat dilihat pada Tabel 6. Pada Tabel 7. Pada pemeriksaan agregat halus dapat disimpulkan bahwa material memenuhi peryaratan yang telah di tetapkan hanya saja agregat dari merapi tidak memnuhi peryaratan akbita kadar lumpur yang terlalu besar mencapai $19,62 \%$, padahal syarat yang di tentukan maksimal sebesar $5 \%$. Sehingga, sebelum digunakan, agregat ini harus di cuci terlebih dahulu.

Tabel 6 Hasil pemeriksaan agregat halus

\begin{tabular}{lccc}
\hline \multicolumn{1}{c}{ Jenis Pemeriksaan } & \multicolumn{3}{c}{ Asal Agregat } \\
& Gamalama & Merapi & Kali Progo \\
\hline Gradasi Butiran & Daerah 4 & Daerah 4 & Daerah 4 \\
Modulus Halus Butir & 2.77 & 3.27 & 2.66 \\
Kadar Air (\%) & 24.66 & 42.19 & 15.00 \\
Berat Jenis & 2.38 & 2.54 & 2.42 \\
Penyerapan Air (\%) & 0.25 & 0.06 & 11.00 \\
Kadar Lumpur (\%) & 2.76 & 19.62 & 3.13 \\
Berat Satuan $\left(\mathrm{g} / \mathrm{cm}^{3}\right)$ & 1.62 & 1.70 & 1.32 \\
\hline
\end{tabular}

Tabel 7 menjelaskan pemeriksaan agregat kasar yang dilakukan dalam penelitian ini adalah berat jenis, kadar air, penyerapan air, berat satuan, kadar lumpur dan nilai keausan. Berdasarkan hasil pemeriksaan nilai keausan hanya agregat dari kali progo yang memenuhi persyaratan sedangkan agregat dari Gamalama dan Merapi tidak memenuhi standar yang ditetapkan yaitu harus kurang dari 40\%. Dari sisi kadar lumpur, agregat merapi termasuk agregat yang tidak memenuhi persyaratan karena persyaratan masimum yang ditentukan hanya $1 \%$.

Tabel 7 Hasil pemeriksaan agregat kasar

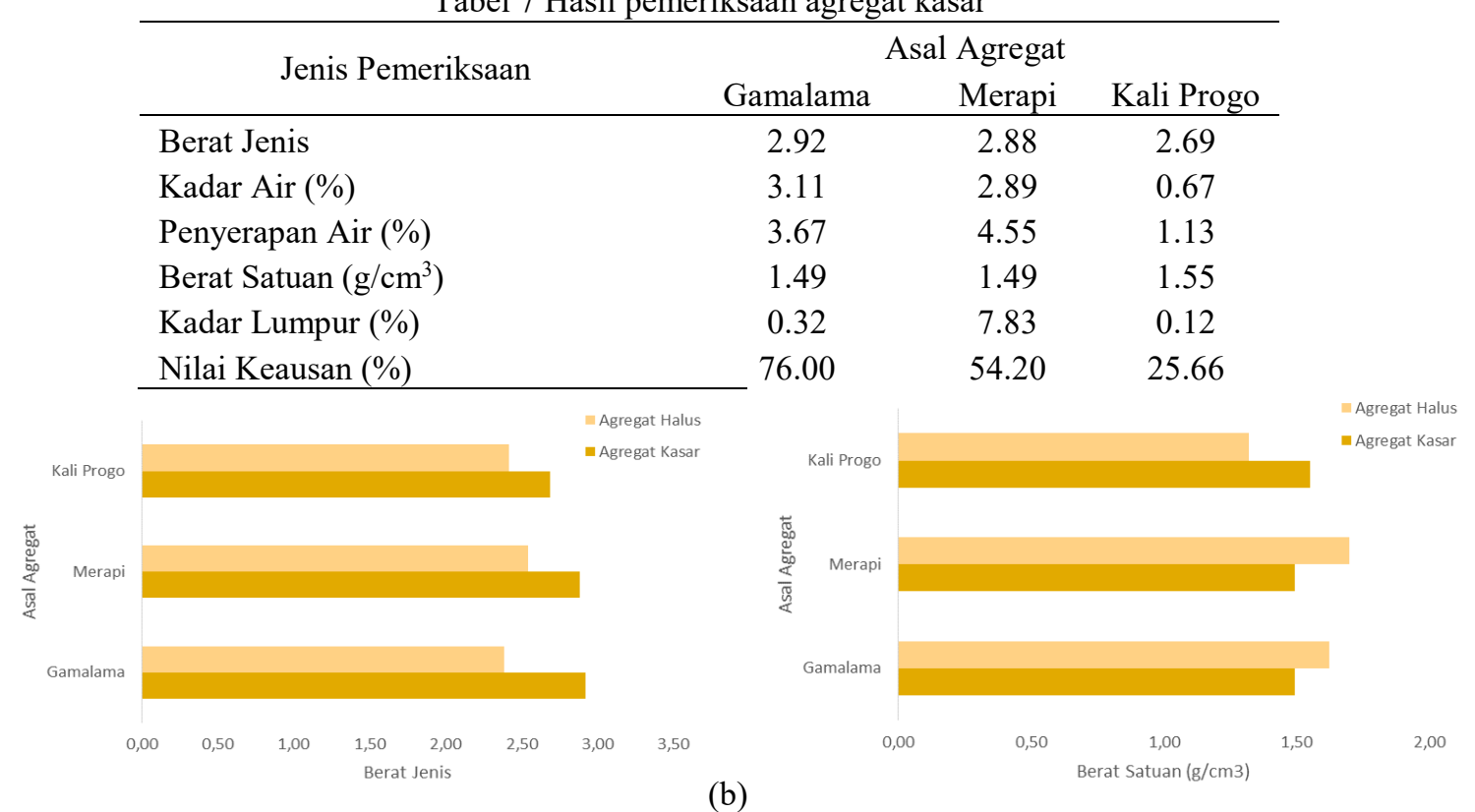

(a) 


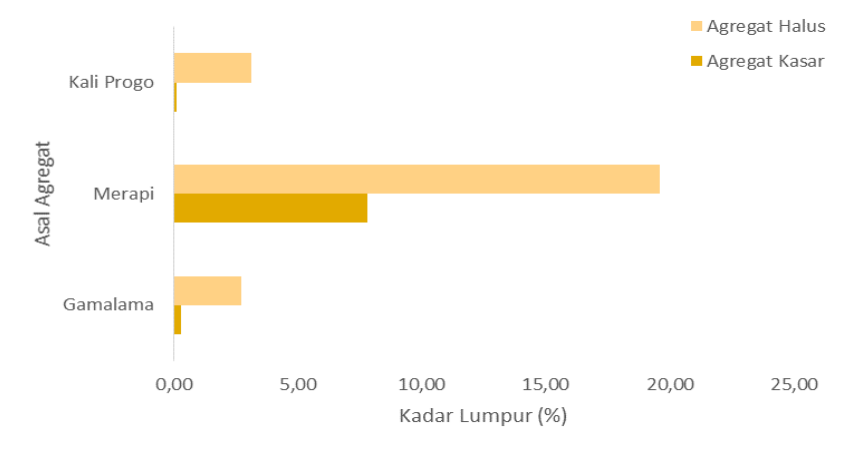

Gambar 2 (a) Hasil pemeriksaan Berat jenis; (b) hasil pemeriksaan berat satuan; (c) hasil pemeriksaan kadar lumpur

Pada Gambar 2 (a) merupakan hasil pemeriksaan berat jenis agregat kasar dan agregat halus untuk seluruh sample sesuai asal agregat nya, terlihat pada Gambar tersebut bahwa setiap daerah memiliki berat jenis yang tidak terlalu berbeda jauh. Sedangakan pada Gamba 2(b) merupakan hasil pemeriksaan berat satuan. Berat satuan terbesar pada agregat halus besaral dari Merapi sedangkan agregat kasar berasal dari Kali Progo. Pada Gambar 2(c) merupakan hasil pemeriksaan kadar lumpur untuk seluruh agregat sesuai asalnya.

\section{Pemeriksaan Nilai Slump}

Pengujian beton segar yang diteliti pada penelitian ini berupa pengujian nilai slump, pengujian ini bertujuan untuk menganalisis nilai workability yang diperoleh.bedasarkan Tabel 8 dapat dilihat bahwa beton menggunakan agregat dari Gamalama memperoleh hasil $10.50 \mathrm{~cm}$, agregat Merapi sebesar $12 \mathrm{~cm}$ sedangkan agregat dari Kali Progo sebesar $7 \mathrm{~cm}$. Pada Gambar 3 merupakan hubungan antara asal agregta dengan nilai slump yang dihasilkan., dapat disimpulkan bahwa nilai slump terkecil diperoleh oleh beton dengan agregat yang berasal dari Kali Progo. Hal ini dibuktikan dengan nilai kadar air dari agregat kali progo, baik agregat halus maupun agregat kasar memiliki nilai yang paling kecil dibandingkan agregat lainnya.

Nilai slump sangat mempengaruhi tingkat kinerja dari beton, kemuhadan pengerjaan yang nantinya dapat berpengaruh pada beton keras, pada beton normal nilai slump yang di haruskan berkisar 8-12 cm, akan tetapi untuk beton-beton dengan kebutuhan khusus, nilai slump terkadang diharuskan dengan nilai yang lebih tinggi, bisa juga dengan nilai yang lebih rendah.

Pada Tabel 6 dan 7 terlihat bahwa terbesar terdapat pada pasir dari Agregat dari Merapi. Hal ini menunjukkan bahwa pasir dari Kali Progo memiliki nilai penyerapan terbesar yaitu 11\%. Maka dari itu dapat disimpulkan bahwa pasir Kali Progo sangat banyak menyerap air pada saat proses pembuatannya sehingga nilai slump yang dihasilkan pun semakin kecil.

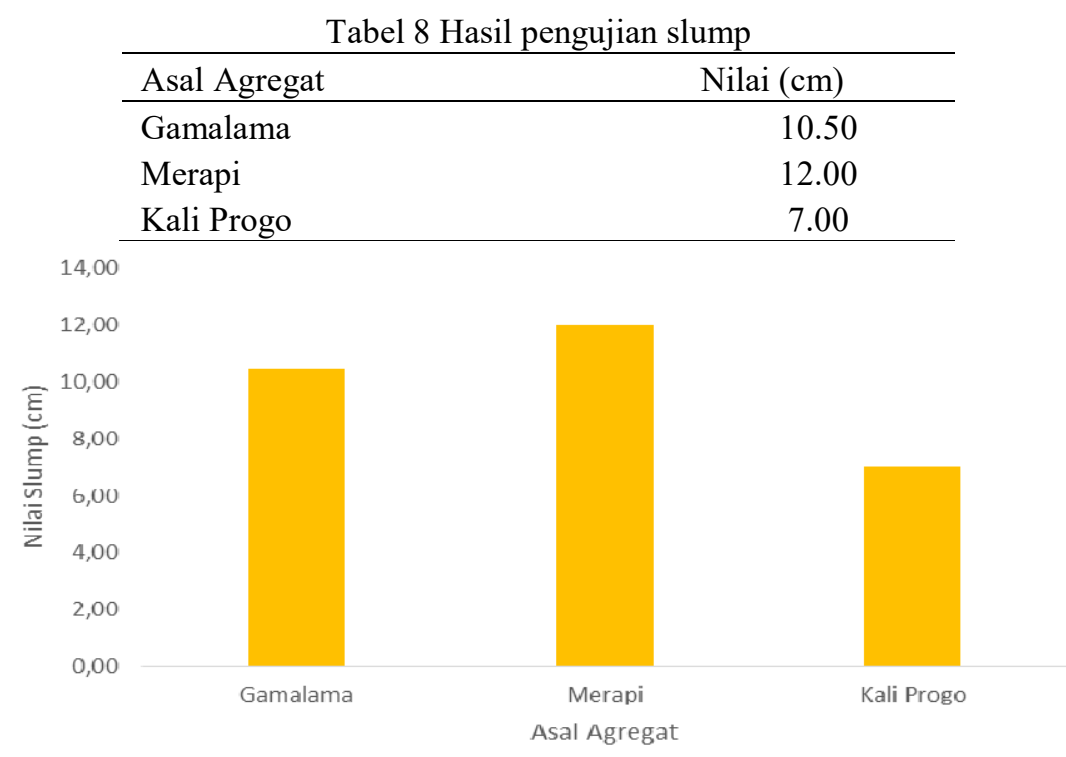

Gambar 3 Hubungan asal agregat dengan nilai slump 


\section{Hasil Kuat Tekan Beton}

Pemeriksaan kuat tekan dilakukan pada umur 7,14 dan 28 haril. Pada Tabel 9 menunjukkan hasil pemeriksaan untuk setiap benda uji nya. Kuat tekan pada umur 7 hari menunjukkan bahwa dengan agregat yang berasal dari gunung gamalama sebesar $36.48 \mathrm{MPa}$, sedangkan agregat dari Merapi memiliki kuat tekan beton sebesar 37.52 $\mathrm{MPa}$ serta kuat tekan beton menggunakan asal Kali Progo sebesar 47.85 MPa. Pada umur 14 hari, beton dengan agregta dari Kali Progo memiliki nilai kuat tekan tertinggi sebesar $67.43 \mathrm{MPa}$, begitu juga dengan kuat tekan beton pada umur 28 Hari.

Pada Gambar 4 merupakan hasil hubungan waktu perawatan dengan kuat tekan beton. Pada Gambaer tersebut terlihat jelas bahwa beton dengan agregat yang berasal dari Kali Progo memiliki kuat tekan paling tinggi dibandingkan dengan benda uji lainnya. Selain itu, dapat disimpulkan bahwa semakin bertambahnya umur beton hingga 28 hari menunjukkan bahwa kuat tekan beton semakin bertambah juga.

Pada Gambar 5 menjelaskan hubungan kuat tekan beton untuk masing-masing asal agregat pada saat beton berumur 28 hari. Seperti yang sudah dijelaskan sebelumnya, beton dengan asal agregat kali progo memiliki kuat tekan tertinggi yaitu sebesar 78,50 Mpa, sedangkan beton dengan asal agregat Gamalama hanya mencapai $72,34 \%$ dari kekuatan beton dengan asal agregat Kali Progo. Beton dengan agregat asal Merapi memiliki kuat tekan 55,88 atau hanya sebesar 71,18\% dari kuat tekan beton dengan agregat asal Kali Progo.

Tabel 9 Hasil pengujian kuat tekan

\begin{tabular}{cccc}
\hline \multirow{2}{*}{ Umur } & \multicolumn{3}{c}{ Asal Agregat } \\
& Gamalama & Merapi & Kali Progo \\
\hline 7 & 33.72 & 37.55 & 46.45 \\
7 & 36.00 & 42.88 & 52.19 \\
7 & 39.71 & 32.13 & 44.91 \\
Rata-Rata (MPa) & $\mathbf{3 6 . 4 8}$ & $\mathbf{3 7 . 5 2}$ & $\mathbf{4 7 . 8 5}$ \\
14 & 48.18 & 49.43 & 66.96 \\
14 & 40.16 & 45.90 & 66.81 \\
14 & 51.43 & 46.35 & 68.52 \\
Rata-Rata (MPa) & $\mathbf{4 6 . 5 9}$ & $\mathbf{4 7 . 2 3}$ & $\mathbf{6 7 . 4 3}$ \\
28 & 55.74 & 53.55 & 77.46 \\
28 & 56.73 & 61.25 & 80.02 \\
28 & 57.90 & 52.85 & 78.02 \\
Rata-Rata (MPa) & $\mathbf{5 6 . 7 9}$ & $\mathbf{5 5 . 8 8}$ & $\mathbf{7 8 . 5 0}$ \\
\hline
\end{tabular}

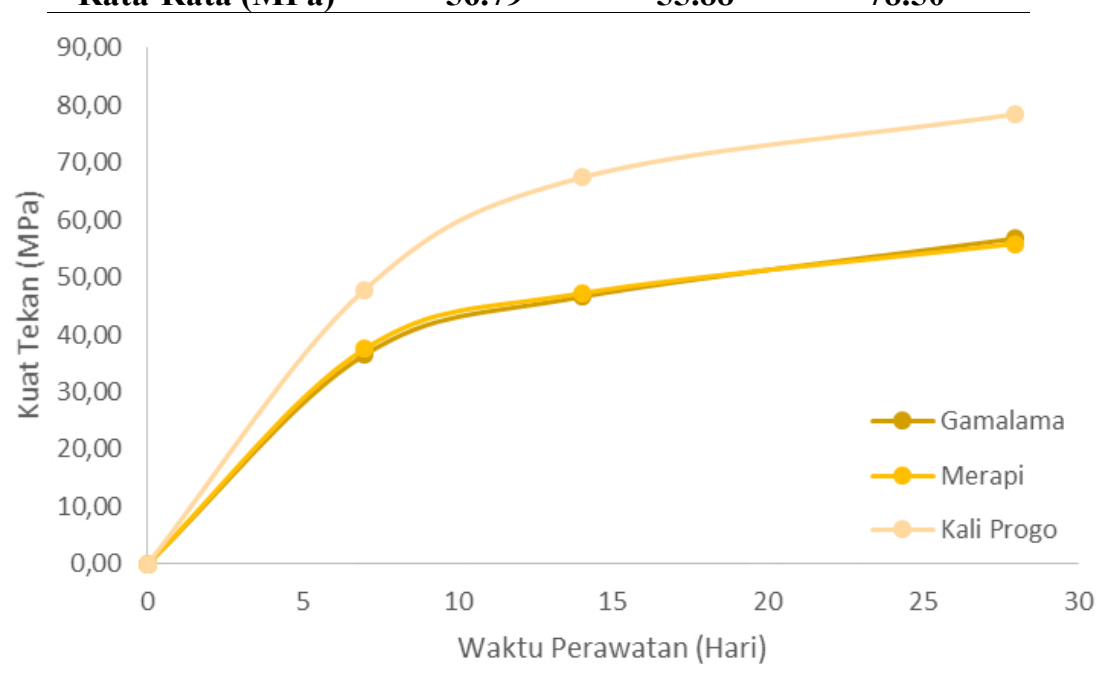

Gambar 4 hubungan waktu perawatan dengan kuat tekan beton 


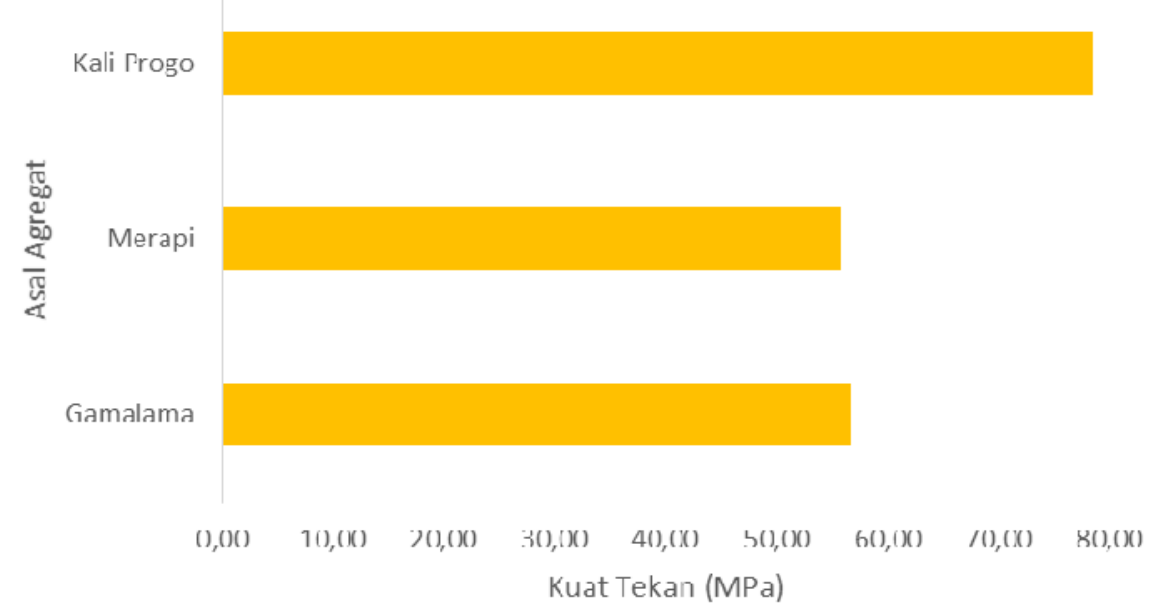

Gambar 5 Hubungan kuat tekan beton pada umur 28 hari dengan asal agregat

\section{KESIMPULAN}

Berdasarkan hasil yang telah didapatkan, maka dapat di simpulkan sebagi berikut.

a. Pemeriksaan nilai Slump yang diperoleh, beton dengan agregat asal Gamalam memiliki nilai $10,5 \mathrm{~cm}$, beton dengan agregat dari Merapi memiliki nilai slump $12 \mathrm{~cm}$ sedangkan nilai slump dengan beton yang berasal dari Kali Progo memiliki nilai $7 \mathrm{~cm}$. hal ini menunjukkan bahwa agregat merapi dan gamalama memiliki tingkat workabilitas yang lebih baik dibandingkan dengan agregat yang berasal dari Kali Progo.

b. Hasil pengujian kuat tekan pada beton umur 28 hari diperoleh dengan agregat Gamalama sebesar 56.79 $\mathrm{MPa}$, Agregat asal Merapi sebesar 55.88 MPa sedangkan beton dengan agregat dari Kali Progo memiliki hasil 78.50 MPa. Dengan mix design yang sama, agregat Kali Progo dapat menghasilkan kuat tekan yang lebih tinggi dan lebih baik dari pada beton yang menggunakan agregat yang berasal dari Merapi dan Gamalama.

c. Hasil pemeriksaan agregat menunjukkan bahwa nilai keausan agregat dari Gamalama dan Merapi cukup tinggi sehingga tidak memenuhi dari standar yang telah ditentukan.

\section{DAFTAR PUSTAKA}

Badan Standarisasi Nasional (BSN). 2002. SNI 03-2834-2002: Tata Cara Pembuatan Rencana Campuran Beton Normal. Depatremen Pekerjaan Umum. Jakarta.

Badan Standarisasi Nasional (BSN). 1989. SNI S-04-1989-F: Spesifikasi Bahan Bangunan Bagian A. Departemen Pekerjaan Umum. Jakarta.

Ervianto, M., Saleh, F., Prayuda, H. 2016. Kuat Tekan Beton Mutu Tinggi Menggunakan Bahan Tambah Abu Terbang (Fly Ash) dan Zat Adiktif (Bestmittel). Jurnal Sinergi 20(3) 2016 : 199-206.

Ikhsan, M.N., Prayuda, H., Saleh, F. 2016. Pengaruh Penambahan Pecahan Kaca Sebagai Bahan Pengganti Agregat Halus dan Penambahan Fiber Optik Terhadap Kuat Tekan Beton Serat. Jurnal Ilmiah Semesta Teknika 19 (2) 2016 : 148-156.

Luga, E., Atis, C.D. 2016. Strength Properties of Slag/Fly Ash Blends Activated with Sodium Metasilicate and Sodium Hydroxide + Silica Fume. Periodica Poytechnica Civil Engineering 60(2) 2016 : 223-228.

Mulyono, T. 2005. Teknologi Beton. Andi. Yogyakarta.

Pratiwi, S., Prayuda, H., Saleh, F. 2016. Kuat Tekan Beton Serat Menggunakan Variasi Fibre Optic dan Pecahan Kaca. Jurnal Ilmiah Semesta Teknika 19(1) 2016 : 55-67.

Tjokrodimuljo, K. 2007. Teknologi Beton. Keluarga Mahasiswa Teknik Sipil Fakultas Teknik Universitas Gadjah Mada. Yogyakarta. 